\title{
Het DNA van Nederland in het Russisch \\ Studentenvertaalproject aan de Lomonosov \\ Staatsuniversiteit te Moskou
}

\section{The DNA of The Netherlands in Russian language \\ Student translation project at Lomonosov State university of Moscow}

Ekaterina Tereshko

\begin{abstract}
The paper presents a practical case of translation of a Dutch book into Russian. The project took place at the Lomonosov State university of Moscow. Russian students who choose Dutch as a second language at the Faculty of Philology participated the translation seminars with the aim to translate the book by Jan Renkema "Het DNA van Nederland" into Russian. A new approach was used in the course: instead of individual passages, one text was chosen, and a modern translation program was used. During the translation, students faced a number of difficulties, both at the text level, and when choosing specific words and expressions for the most accurate transfer of meaning. These challenges are listed in the paper.
\end{abstract}

\section{Keywords}

translation, Dutch, Russian, identity, CAT-tools, transformations 
Naar aanleiding van Colloquium Neerlandicum 2018 in Leuven ben ik, docent Nederlands aan de Lomonosov Staatsuniversiteit te Moskou, op het idee gekomen om het laatste boek van Jan Renkema „Het DNA van Nederland“, samen met mijn studenten naar het Russisch te vertalen. Gelukkig stemde de auteur hiermee in en konden we dit gaan doen.

De keuze is op dit boek gevallen om drie redenen. Ten eerste heeft het thema van dit boek - de Nederlandse identiteit - twee kanten, en is daarom een uitdaging voor de vertaler. Aan de ene kant is het thema actueel in de hedendaagse wereld. Aan de andere kant blijft „de identiteit“ moeilijk om vanuit een buitenlandse visie uit te leggen. Ten tweede is het boek overzichtelijk qua omvang: het plan was om het binnen een cursus van twee semesters te vertalen. Ten derde is de auteur, Jan Renkema, een erkende taalkundige in Nederland en het is daarom ook interessant en uitdagend om zijn tekst te mogen vertalen.

\section{Nieuwe aanpak cursus Nederlands}

\section{Motivatie}

Met het boek „Het DNA van Nederland“ zouden in de jaarlijkse vertaalcursus Nederlands-Russisch ook aanpassingen komen. De belangrijkste verandering was een verschuiving van operational work, d.w.z. werken aan verschillende teksten gedurende het jaar zonder een tastbaar resultaat, naar project work dat wel een resultaat oplevert. Om een haalbaar project van deze vertaling te maken was het heel belangrijk dat het boek niet te lang en makkelijk in te delen was.

Het oude cursus-format was verbonden aan de cursus Nederlandse literatuur en hield in dat de studenten tekstfragmenten vertalen van verschillende auteurs die ze voor het vak moeten lezen. Er was dus geen einddoel en geen duidelijk resultaat wat de motivatie van de studenten deed dalen.

De nieuwe aanpak van de vertaalcursus als project had twee doelen voor ogen. Ten eerste de motivatie van de studenten te doen stijgen en ten tweede nieuwe vertaalinstrumenten, namelijk moderne vertaalprogramma's, aan hen te laten zien.

Deze nieuwe aanpak heeft zijn voor- en nadelen in vergelijking met het oude format. Wat de voordelen betreft biedt zo'n project een duidelijk doel aan de studenten zodat ze weten waar ze naartoe werken: het boek moet vertaald en uitgegeven worden. Bovendien heeft het feit dat de studenten langere tijd met één tekst werken als gevolg dat de tekst dieper begrepen wordt. De verbanden binnen de tekst die niet op het eerste gezicht te zien zijn, kunnen beter naar boven komen en vertaald worden. De vertaalde tekst krijgt op zo'n manier meer diepgang.

Het werk aan de vertaling werd in groepen georganiseerd: in iedere groep was een vertaler, een redacteur en een corrector. Op deze manier werd de samenwerking onder de studenten van verschillende jaren (de cursus werd gegeven aan de studenten van de 2-de en 3-de jaars bachelor, 7 studenten in totaal) gestimuleerd en werden de principes van de peer-teaching ${ }^{1}$ methode toegepast. 
Omdat iedere student in alle rollen (vertaler, redacteur, corrector) moest kunnen proberen te werken, werd deze kans zowel aan de studenten van 2-de jaars als aan de studenten van 3-de jaars gegeven. Het is echter gebleken dat de rol van vertaler als de gemakkelijkste werd ervaren. Dat kon dus iedereen individueel doen, terwijl de rollen van redacteur en corrector moeilijker leken en voor de redactie en correctie werden er paren gevormd waar één student in zijn/haar tweede jaar Nederlands zat en één in zijn/ haar derde jaar. Het feit dat alle studenten van de groep het Nederlands als keuzevak studeren heeft ervoor gezorgd dat de communicatie in paren soepel verliep: men had de neiging eerder elkaar te helpen dan te laten zien dat hij/zij iets beter kan.

Aan de andere kant kunnen er ook nadelen van de gekozen aanpak benoemd worden: het werken aan een tekst gedurende het hele jaar laat veel nuances van de tekst naar boven komen en dat betekent dat er ook steeds terugblikken en veranderingen van eerder vertaalde delen van de tekst komen. Dat laat de studenten zien hoe moeilijk het is om vertaler te zijn. Bovendien komen er ook problemen in de samenwerking: studenten vinden het soms moeilijk om kritiek van de medestudenten te accepteren. Hoewel deze nadelen ook als voordelen beschouwd kunnen worden als de studenten deze moeilijkheden te boven komen. Op zo'n manier leren ze zich concentreren op een tekst, op een taak. Ze leren doorgaan zelfs als het moeilijk is. Bovendien leren ze met elkaar op een tolerante en zakelijke manier te communiceren om samen het doel van het project te bereiken.

\section{CAT-tools}

Het vertaalproject is deels digitaal uitgevoerd. De vertalingen werden gemaakt en gecorrigeerd in een gratis CAT-vertaalprogramma (Computer Aided Translation). De studenten maakten kennis met moderne mogelijkheden om te vertalen, wat hen meer kansen biedt op de Russische vertaalmarkt. Bovendien maakte het gebruik van digitale middelen het project voor alle deelnemers inzichtelijk: iedereen kon zien wie, wanneer en wat heeft vertaald of wat er in zijn/haar vertaling door de anderen werd veranderd.

Voor dit project hebben we een gratis CAT-tool "SmartCAT" gebruikt. In dit programma werd een digitaal project gestart waartoe de docent, alle studenten en Jan Renkema toegang hadden. In dat programma werden ook de opdrachten voor de vertalingen redacties en correcties uitgedeeld door de docent. De studenten kregen dus digitaal een opdracht en de docent en de medestudenten konden zien wie, wat en wanneer doet op de interface van het gebruikte programma. De "reminders" werden ook via de e-mails verspreid.

De studenten kregen ook de kans om vragen aan Jan Renkema te stellen. Het kon op twee manieren gebeuren: direct via de CAT-tool of via de docent. Ze durfden echter niet vaak van deze gelegenheid gebruik te maken. Ten eerste, ligt het aan de Russische identiteit (of wel aan de Russische DNA). De Russische cultuur is gemarkeerd als "afstandelijk"

1 Topping, Keith, Buchs, Célline [et al] (2017): Effective Peer Learning: From Principles to Practical Implementation. New York: Routledge. 192 p. 
en "hiërarchisch" en het is dus niet gebruikelijk om een "bovenstaande" persoon te contacteren, men moet eerst zijn vragen zelf proberen op te lossen. Ten tweede, kan het zijn dat de studenten weinig vragen aan de auteur van het boek stelden want ze wilden niet toegeven dat ze iets niet begrepen. De vragen werden echter wel in de klas besproken en de moeilijke plaatsen die na de bespreking nog niet helemaal duidelijk waren werden aan de auteur van het boek gestuurd opdat hij die zou uitleggen. De studenten verheugen zich ook op de komt van Jan Renkema die voor de aanstaande november gepland is.

\section{Uitdagingen van de tekst}

$\mathrm{Na}$ het project te hebben beschreven wil ik nu de aandacht van de lezer richten op de tekst zelf. Er zijn redelijk veel fragmenten die uitdagend voor de studenten waren, mede door de cultuurverschillen tussen Nederland en Rusland.

De cultuurverschillen hebben een weerspiegeling in de taal. Daarover schreef Artur Langeveld in zijn boek „Vertalen wat er staat“2. Hij beschrijft nuances van het gebruik van het voorzetsel in in het Russisch en in het Nederlands: in het Russisch is Het boek ligt

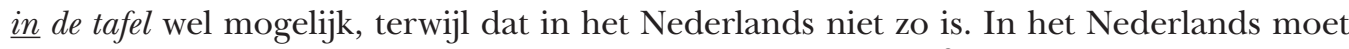
deze zin uitgebreid worden: Het boek ligt in de la van de tafel $^{3}$. Hij concludeert daaruit: een-op-een correspondentie van woorden in verschillende talen bestaat niet.

Naar onze ervaring met het vertaalproject waarin het boek „Het DNA van Nederland“ centraal staat, bestaan er nog andere nuances op verschillende niveaus van de tekst die ik hier probeer op te sommen.

\section{Genre}

Voordat we begonnen met vertalen moesten de studenten zichzelf de vraag stellen wat voor tekst voor hen lag. Het bleek redelijk moeilijk om het genre van dit boek te bepalen. Russen zijn er namelijk aan gewend dat fictie verzonnen is en alles wat niet verzonnen is moet wetenschappelijk zijn of over feitelijke gebeurtenissen gaan. Informatieve teksten zijn niet wijd verspreid op de Russische boekenplanken terwijl het in Nederland andersom is.

Hoe bepaal je het genre van een informatieve tekst? Het boek begint met een verzonnen dialoog wat aan fictie doet denken, maar daarna komen er informatieve feiten over Nederland. Die feiten kunnen anders ook als mening worden beschouwd. Met zo'n redenering kwamen de studenten op non-fiction als bepaling voor dit boek. Dat bracht ook wat moeilijkheden met zich mee: in zulke teksten moet zowel de informatie als de stijl bewaard worden en kan men niet het ene voor het andere opofferen.

2 Langeveld, Artur (2012): Vertalen wat er staat. Amsterdam/Antwerpen: Uitgeverij Atlas Contact. 207 p.

3 Langeveld, Artur [footnote 2], pp. 38-39. 


\section{$U$ en jij}

Hoofdstuk 1 Een gesprek boven de oceaan, richting Schiphol begint met het gesprek in de vorm van een dialoog:

- Kunt u me vertellen, wat voor land is dat eigenlijk, Nederland?

- U bedoelt toch niet de Nederlandse identiteit? ${ }^{4}$

Er komen meteen twee opmerkingen naar voren over deze eerste regels van het boek. Ten eerste is het niet duidelijk of het gesprek zo pardoes begint of dat we midden in het gesprek vallen. En ten tweede is er de vraag of je $u$ vertaalt met $u$ of met $j i j$ in het Russisch.

Aan de ene kant is het voor Russen normaal om te vousvoyeren. Zo beginnen we een gesprek met alle onbekenden, onder andere zeggen we $u$ tegen de medereizigers in het vliegtuig. Aan de andere kant is dit in Nederland niet altijd zo en daarom komt er nog een vraag: waarom zeggen die twee personen $u$ tegen elkaar? Willen ze gewoon beleefd zijn of zijn het oudere mensen? Zou het neutraal zijn of is dat een gemarkeerde beleefdheid? Die vragen komen in de studenten op want op de universiteit leren ze dat de Nederlanders veel vaker dan de Russen tutoyeren.

Als oplossing hebben we voor onze vertaling toch $u$ gekozen, net zoals in de auteurs tekst. Maar er zijn ook nuances. In het Russisch zijn er twee manieren om $u$ te schrijven: met een hoofdletter, of met een kleine letter. De eerste wordt gebruikt in officiële en plechtige brieven of andere documenten, de tweede zie je in fictieboeken, e-mails en krantenteksten. In de vertaling schrijven we dus $в ъ$ ' 'u' met een kleine letter zodat de beleefdheid (we nemen aan dat de gesprekpartners elkaar niet kennen) uitgedrukt wordt, maar niet te plechtig.

\section{Alinea's en zinslengte}

Omdat de tekst van een informatief karakter is zoals de Nederlanders gewend zijn, zijn sommige zinnen en alinea's redelijk lang. Als je die naar het Russisch vertaalt worden ze nog langer, want Russische formuleringen zijn vaak langer dan de Nederlandse. Daar zijn de Russische lezers niet aan gewend, dus moesten sommige zinnen in twee of meer gedeeld worden. Dat was vooral nodig bij de opsommingen, die vaak in de tekst voorkomen:

...polder-dijk-molen, koe-melk-kaas, klomp, tulp, turf, haring, erwtensoep-boerenkool-spruitjes, pannenkoek, schaats, fiets... (p. 5)

...elf boeken, twaalf gedichten, dertien kunstwerken, veertien Nederlandse bijdragen aan de wereldtentoonstellingen tussen 1910 en 2015, en de geschiedenis van vijftien prototypische Nederlanders... (p. 6)

Er waren ook situaties waar we het andersom moesten doen: twee zinnen of alinea's tot één samen laten smelten zodat het in het Russisch natuurlijk zou klinken.

4 Renkema, Jan (2017): Het DNA van Nederland. Amsterdam: Boom. 63 p. 


\section{Typisch Nederlandse verwijzingen}

Er staan vaak verwijzingen in de tekst, die helemaal onbekend zijn voor de Russische lezer. Die links moesten de studenten opzoeken en uitleggen aan de toekomstige lezers van het boek. Daardoor leerden ze de Nederlandse cultuur beter kennen en ze moesten ook iedere keer een oplossing vinden voor de vertaling. Om een paar voorbeelden te noemen:

(1) Ik heb vijf mooie videocolleges van Lotte Jensen gevolgd over Nederlander Zijn... (p. 5) Например, я посмотрел пять отличных видео-лекций Лотты Йенсен о нидерландской идентичности...

letterlijk: Bijvoorbeeld, ik heb vijf mooie videocolleges van Lotte Jensen gevolgd over de Nederlandse identiteit...

(2) Ik heb ook een prachtig boek gelezen vol wetenswaardigheden, van Herman Pleij. Moet nog steeds kunnen, ook uit 2016, hoe Nederlanders door de eeuwen heen op zoek zijn gegaan naar hun identiteit. (p. 6)

Ещё я прочитал занимательную книгу «Это имеет право на жизнь» (Херман Плей, 2016). В ней говорится о том, как долго нидерландцы искали свою идентичность.

letterlijk: Ik heb ook een prachtig boek "Moet nog steeds kunnen" (Herman Pleij, 2016) gelezen. Het gaat over hoelang Nederlanders naar hun identiteit zijn gegaan.

(3) Of met een variant op een beroemde uitspraak van de beste voetballer aller tijden, onze eigen Johan Cruiff: "Het water kan niet van ons winnen, maar wij kunnen wel van het water verliezen - als we niet samenwerken”. (p. 15)

Вот вариация на знаменитое высказывание лучшего футболиста всех времен, нашего земляка Йохана Крёйффа: «Вода не может нас победить, но мы можем проиграть, если не будем работать вместе».

letterlijk: Hier is een variant op een beroemde uitspraak van de beste voetballer aller tijden, onze landgenoot Johan Cruiff: "Het water kan niet van ons winnen, maar wij kunnen wel verliezen, als we niet samenwerken”.

Voorbeeld (1) vereist een link naar de lezingen die we aan het eind van het boek zullen plaatsen. In voorbeeld (2) is het duidelijk dat het om een boek gaat, daarom hebben we de naam van de auteur en het jaar van het boek tussen haakjes gegeven wat in Russische teksten gebruikelijk is. In voorbeeld (3) wordt in de tekst zelf uitgelegd wie Johan Cruiff is en het is in de vertaling ook zo gebleven.

Behalve de verwijzingen naar voor de Russen onbekende Nederlanders zijn er ook verwijzingen naar typisch Nederlandse gewoontes en verschijnselen. Bijvoorbeeld Zwarte Piet, die op pagina 7 wordt genoemd. Dat vereist ook een noot en dat is nodig in de vertaling. Maar die link moet uitgebreid zijn, want tussen haakjes komt er nog te staan dat die Zwarte Piet ook een roetpiet is. En daarachter zit het hele verhaal rond Sinter- 
klaas en Zwarte Piet: moeten we deze traditie bewaren of afschaffen, een discussie die nog steeds gaande is in Nederland.

Er is ook een bespreking van de regel uit Wilhelmus "ik ben van duitse bloed". Deze zin is moeilijk te vertalen om twee redenen. Ten eerste kent een Russische lezer het Nederlandse volkslied niet. Ten tweede is het ingewikkeld om uit te leggen wat het woord duits (maar ook diets) in dit lied betekent. In de vertaling hebben we het woord germaans gebruikt, dat ook voor de Germaanse talen, waaronder Duits, Engels en Nederlands, wordt gebruikt. Middels de verwantschap van deze talen wordt in de Russische tekst de link gelegd naar het begrip dat achter de regel "ik ben van duitse bloed" zit.

\section{Herhalingen en synoniemen}

Het informatieve karakter van de Nederlandse tekst laat toe dat bepaalde woorden steeds herhaald worden. Als voorbeeld kunnen we deze alinea nemen:

Of neem waarden. Een waarde is bijvoorbeeld 'vrijheid van meningsuiting'. Maar zo'n waarde geldt ook voor Zweden of Amerika. Waarden kun je concretiseren in normen. Bijvoorbeeld de waarde 'respect', ook voor een tegenstander of andersdenkende, uit zich in de gewoonte dat je elkaar ook na een pittig debat een hand geeft. Zo'n gewoonte kan dan een norm worden waaraan je moet voldoen. Maar wat zegt dat over identiteit? (p. 9)

Neem het woord "waarde": in dit stuk is het in de eerste vijf zinnen vier keer herhaald. Dat kan niet in de Russische tekst en het werd een grote uitdaging voor de studenten. Ze hebben daarvan het volgende gemaakt:

Давайте поговорим о наших ценностях. Например, о свободе выражения. Но ведь в Швеции и Америке самовыражение тоже играет большую роль и это определяет нормы поведения. Возьмём уважение: так ваш оппонент выражает своё почтение, пожимая вам руку после жаркой дискуссии. Это поведение становится нормой этикета. Но разве это имеет отношение к идентичности?

letterlijk: Laten we het over onze waarden hebben. Bijvoorbeeld over de vrijheid van meningsuiting. Maar in Zweden en Amerika speelt zo'n zelfontplooing ook een grote rol en dat bepaalt de gedragsnormen. Neem maar 'respect': je opponent uit zijn respect door uw hand te schudden na een pittig debat. Zo'n gedrag wordt een omgangsvorm. Maar heft het iets met de identiteit te maken?

In de vertaling is te zien dat er veel minder herhalingen zijn. Daarvoor moesten de studenten de woorden "normen" en "waarden" weglaten, omschrijven of synoniemen daarvan gebruiken.

Hetzelfde geldt voor woorden die vaak in de tekst voorkomen, bijvoorbeeld identiteit. 


\section{Moeilijke begrippen}

Sommige begrippen die in de tekst voorkomen leken ook een uitdaging voor de studenten te zijn. Dat zijn vooral begrippen die in het Russisch uit de Europese talen zijn ontleend en vooral in informatieve teksten (dus als in het boek ongewenste woorden van bureaucratische stijl ${ }^{5}$ ) worden gebruikt. Het gaat bijvoorbeeld over de woorden privacy, privéleven, en weer identiteit, normen en waarden enz. Zulke begrippen werden eerst omschreven in de tekst waarna ze verder als termen konden worden gebruikt. De studenten moesten ook altijd aandachtig zijn om ze niet te veel in het Russisch te gebruiken, anders zou de tekst te officieel en saai klinken wat niet de bedoeling was.

Bovendien, was het moeilijk om zulke typisch Nederlandse begrippen als bijvoorbeeld gezellig en gezelligheid te vertalen. In deze gevallen deden de studenten dat op basis van de gegeven context, dus er zijn verschillende varianten van de vertaling van deze woorden in het boek.

Om zo'n kantoorstijl te vermijden moesten sommige begrippen zelfs weggelaten worden. Dus in de zin

Dus u wilt echt in een paar zinnen iets horen over onze identiteit, terwijl er al vele studies zijn verschenen, talrijke reisverslagen van buitenlanders door de eeuwen heen, tientallen vermakelijke en handzaam gebundelde columns van buitenlanders en expats, en van mensen met een migratieachtergrond? (p. 7)

То есть в двух словах рассказать об идентичности? Что же добавить, когда есть много исследований, заметок путешественников разных времен, десятки занимательных и полезных статей?

letterlijk: Dus u wilt dat ik in een paar woorden over de identiteit vertel? Wat kan ik daaraan toevoegen wanneer er veel onderzoeken, reisverhalen van de reizigers allertijden, tientallen vermakelijke en nuttige artikelen bestaan?

worden die expats en mensen met migratiegrond weggelaten want deze benamingen klinken te officieel voor een onderhoudend boekje in het Russisch. We nemen dan aan dat deze begrippen vallen in talrijke reisverslagen van buitenlanders door de eeuwen heen.

\section{Ironie}

Soms klinkt in de Nederlandse tekst een zekere ironie door. Bijvoorbeeld, als we het over het boek van Herman Pleij hebben, staat er:

Maar dat boek is toch wel een beetje merkwaardig af en toe, bijvoorbeeld die opmerking over een mooi park bij jullie, De Hoge Veluwe als 'groot uitgevallen kerststukje, of jullie nationale feestdag, Koningsdag, met de vrijhandel op de trottoirs en dan een zin als "Binnen 24 uur verhuist een enorme vracht rotzooi van de ene zolder naar de ander."

5 Галь, Нора (2017): Слово живое и мертвое. (Het woord levend en dood) Санкт-Петербург: Азбука. 352 c. 
In het Russisch moesten de omschrijvingen heel nauwkeurig worden gekozen om deze soepele Nederlandse ironie weer te geven:

Но иногда эта книга меня удивляет. Особенно, когда автор называет ваш красивый парк Де-Хохе-Велюве «растерзанным рождественским букетом», а национальный праздник День Короля сравнивает с гаражной распродажей под девизом «За сутки куча барахла успевает переехать с одного чердака на другой». letterlijk: Maar soms verbaast me dit boek. Vooral als de auteur uw mooie park De Hoge Veluwe een "gemartelde kerstbos" noemt en de nationale feestdag de Koningsdag met een garage uitverkoop vergelijkt onder de motto "Binnen 24 uur verhuist een hoop rommel van de ene zolder naar de ander".

De vergelijking met een kerststukje zal bij de Russen niet veel oproepen, zij hebben zo'n traditie niet. Dat maakt het lastig te vertalen, wat ook hierboven al als een pittige opgave werd genoemd.

\section{Conclusie}

Het boek dat aanvankelijk te vertalen leek in twee semesters bood veel meer uitdagingen dan we verwachtten. Sommige van die uitdagingen zijn in dit artikel opgesomd. Na de laatste redactie komen er misschien nog enkele bij. Op dit moment zijn de studenten nog bezig met het boek en ze doen hun best om het tegen het eind van het derde semester klaar te hebben. Wat daar goed aan is? Ze verliezen de moed niet maar worden juist extra gemotiveerd door al die hindernissen die ze tegenkomen.

\section{Literatuur}

Langeveld, Artur (2012): Vertalen wat er staat. Amsterdam/Antwerpen: Uitgeverij Atlas Contact. 207 p. Renkema, Jan (2017): Het DNA van Nederland. Amsterdam: Boom. 63 p.

Topping, Keith, Buchs, Célline [et al] (2017): Effective Peer Learning: From Principles to Practical Implementation. New York: Routledge. 192 p.

Галь, Нора (2017): Слово живое и мертвое. (Het woord levend en dood) Санкт-Петербург: Азбука. 352 с.

Ekaterina Tereshko, Ph.D. student, Dutch lecturer / katja.tereshko@yandex.ru Lomonosov State university of Moscow, Faculty of Philology, Department of German and Celtic Philology Leninskye gory - 1/51, The first humanities building, 119991 Moscow, RU 
